combined with phosphate gave marked increases in yield, but the cost of treatment is high ( $£ 5-8$ per acre) owing to the long road haul from the nearest railhead, and the expenditure may not be worth while in view of the risks of crop failure. In Kenya, small significant increases in yield of wheat were caused by potash in one year, but in the two following years the response was negligible, and it is possible that this transitory effect was due to the particular seasonal conditions in the first year. Even when no yield increases were obtained, the grain from the potash plots was noticeably plumper than that from other treatments.

Both in Kenya and Tanganyika, potash had no definite effects on the yield of pyrethrum flowers ; it was thought at one time that lack of potash might be connected with the incidence of Ramularia bud disease, but no conclusions on this point can yet be drawn. Tobacco experiments in the Southern Highlands of Tanganyika showed increases in yield which were directly dependent on the amount of potash applied, and the highest yields were given by a balanced NPK mixture which produced more than 78 per cent of high-grade leaf. Coffee gives no response to potash in East Africa, and on the whole most tea soils are well supplied with potash, but the tea crop drains the potash reserves, since the $\mathrm{K}_{2} \mathrm{O}$ content of the tea 'flush' may be as high as 2.5 per cent.

Healthy sisal in Tanganyika does not seem to respond to potash, and it has been noticed that excess potash results in acute chlorotic mottling even if lime and phosphate are adequate. This is curious in view of the fact that banding disease, which is prevalent in parts of Tanganyika, is primarily due to potash deficiency, and several estates are now applying potash as a routine. It has been suggested that the soil $K / N$ ratio is important in controlling the uptake of potassium by plants, and that a $\mathrm{K} / \mathrm{N}$ ratio of 0.05 is critical.

Applications of lime have given increases in yield in a few field trials, but on the whole liming has not given responses in East Africa with wheat, maize, sorghum, groundnuts, pyrethrum or coffee. There is some evidence that Kenya soils are not likely to react to lime when they are less acid than $p \mathbf{H} 5 \cdot 2$, but above this acidity there is no certainty that liming will be beneficial. Sisal is a gross ealcium feeder, and continuous sisal growing on red earths leads to progressive acidification of the soil. Chlorotic mottling of sisal is reduced by applications of limestone, and it seems possible that this disease is related to excessive uptake of minor elements; excessive cobalt has been reported in leaves showing chlorotic mottling. It is sometimes stated that sisal plants grown on soil which is low in calcium tend to be more susceptible to bole rot; but a definite association between the two has not yet been confirmed.

With organic manures, the most striking results were obtained on hill sands in the Lake Province of Tanganyika, where the residual effects of cattle manure at 3 or 7 tons per acre have persisted for eight years on cotton rotated with bulrush millet. Equivalent amounts of nitrogen and phosphate gave results similar to, or greater than, these organic dressings, but only in the year of application. Cattle manure is particularly effective on the highly leached soils of the thinly populated upper Kikuyu bracken lands in Kenya, where applications of the major fertilizers are not very effective. In addition to these striking and as yet unexplained effects of organic manures, there appears to be an overall response to cattle manure and compost on most food crops in most areas of East Africa. The fact that cattle manure is not widely used by African farmers is probably explained by the labour involved in transport and application, and it may be the comparative lack of wheeled transport that is the underlying cause of this reluctance to return plant and animal residues to the soil.

With coffee, mulching has proved to be much more effective than compost or cattle manure, both in Kenya and in Tanganyika. From studies of the soil moisture relationships it has been shown that the effect of mulching is far greater in assisting the penetration of rain than in impeding evaporation during the dry season. Thus coffee planters are advised to apply mulch at the onset of the rainy season, field trials having shown that the yield in a dry year could be increased by 100 per cent, while a 75 per cent increase may be obtained in a year of normal rainfall

The microbiological aspects of the nitrogen cycle in soil are being studied at Muguga, since it has been recorded by the Uganda Department of Agriculture that large amounts of nitrate (up to 300 p.p.m.) can accumulate in the top inch of bare fallow soil, with a sharp drop to 50 p.p.m. in the second inch and a rise to 300 p.p.m. at a depth of about 3 feet. In shaded or mulched soil only very small amounts of nitrate are found (less than 10 p.p.m. in the top six inches), while cropped soils show varying amounts, less than bare fallow but more than shaded soils. The basic explanation of these field-results is not yet complete, since they do not fit into the usual pattern of microbiological action, and further work, in both field and laboratory, is being carried out.

For some years deficiencies and excesses of minor elements, in both crops and stock, have been suspected in East Africa, but it is only recently that facilities for spectrographic estimation of these has been made available. Zinc deficiency may be involved in phosphate response, copper deficiency in coffee has been indicated by growth responses to fungicidal sprays containing copper, excess cobalt has been reported in sisal leaves showing chlorotic mottling, and some evidence of calcium deficiency caused by excessive uptake of manganese has been found in coffee in Tanganyika. A recent observation by the Fisheries Research Organization that the waters of Lake Victoria are abnormally low in sulphur points to the need for study of this element in the crops and soils of the vast drainage basin of that lake.

${ }^{1}$ E. Afr. Agric. J., 15, 61 (1949).

\section{TENTH INTERNATIONAL PHYTOGEOGRAPHICAL EXCURSION}

THE International Phytogeographical Excursion held in Spain this year was the tenth of the series which began in the British Isles in 1911 ; it consisted of two parts, the first starting from Barcelona on June 25 and ending at Madrid on July 15, and the second beginning at Madrid on July 16 and returning there on July 22 . Twenty-six visiting botanists of twelve different nationalities took part, some for both parts of the excursion, some for only one, in addition to Profs. Don Salvador Rivas-Goday and Don Fernández-Galiano, who led 
the party, and other Spanish botanists who accompanied it for varying periods in the districts of which they had special knowledge. Dr. Werner Lüdi, the well-known Swiss phytogeographer and chairman of the international committee responsible for organizing the excursions, was the director on this occasion. Like its predecessors, the excursion in Spain was both scientifically profitable and enjoyable. Much ground was covered, as the route extended from Barcelona in the north-east to Lugo in the north-west and the Sierra Nevada in the south, so inevitably there was little time for intensive study of any one locality or of the numerous and fascinating ecological and phytogeographical problems which arose at every step. Nevertheless, all who took part in the excursion felt that they had enjoyed an incomparable opportunity of seeing a number of representative and very diverse regions of a country which has perhaps no equal in Europe as a field for ecological study.

The party travelled in a diesel motor-coach, large enough to accommodate them all, together with a technical assistant and the baggage, and the skill with which the drivers of this somewhat cumbrous vehicle negotiated narrow and difficult mountain roads was quite remarkable. This method of travel not only allowed the maximum freedom in the choice of route but also allowed stops to be made for photography or note-taking wherever the vegetation seemed particularly interesting.

The first area studied was the curious rocky ridge of Montserrat, which made an excellent introduction to the rich flora of the coastal region of Catalonia with relatively luxuriant maquis vegetation depending on mild winters and not excessively dry summers. From there, travelling via Lérida to Saragossa, the party crossed the arid region of los Monegros in Aragon, where a rainfall of less than $300 \mathrm{~mm}$., combined with cold winters, very hot summers and a porous gravelly soil (derived from alluvial beds of Oligocene age), gives rise to a very scanty covering of vegetation. Xerophytes such as Capparis spinosa, Peganum harmala and Lygeum spartum are common; but though the vegetation has the appearance of a very dry steppe, almost of a semi-desert, occasional relics of Quercus ilex, Pinus halepensis and Juniperus thurifera show that the climax is woodland and that the Spanish botanists are right in terming it a 'pseudo-steppe'. The potentially most fertile land in this dry region lies, of course, in the moister hollows and river valleys, but cultivation is often prevented or impeded by high concentrations of gypsum and other salts. Many of the damp hollows are still occupied by a natural vegetation of halophytes such as Salicornia sp., Suceda fruticosa var. brevifolia, etc., but where irrigation water is available rice is successfully cultivated.

After a brief visit to the central Pyrenees, including the impressive National Park of Ordesa, the excursion continued north-westwards to Pamplona and then via Logroño and Soria to Burgos. The journey along the southern foothills of the Pyrenees was an interesting demonstration of the gradual change in the vegetation from the dry continental conditions of Aragon to the moister and more Atlantic conditions of Navarre. Atlantic plants such as Erica vagans and many of the common British wayside species gradually increased in abundance, and near Pamplona meadows of true sward-forming grasses at low altitudes were seen for the first time. Evidence of a still more markedly Atlantic climate was seen in the highlands of the Macizo Ibérica between Logroño and Soria, where at altitudes above $1,000 \mathrm{~m}$. there are extensive heaths of Calluna, Erica aragonensis, etc., reminiscent of the moorlands of Ireland and Scotland. Some characteristically 'British' plant communities, such as a 'wet heath' with Nardus, Juncus squarrosus, Sphagnum spp., etc., were met with here.

After Burgos the route, before turning south-east towards León and Castile, passed through the Cantabrian mountains to the Asturias and Galicia, the region of Spain with the most strongly developed oceanic climate and vegetation. The luxuriant roadside vegetation of the Asturias with its abundance of Daboecia, species of Erica and, in places, of Osmunda, recalled Cornwall and south-west Ireland, though the fields of maize and the vines around the houses testified to higher summer temperatures. It was interesting to see, in the Asturias, enclosed fields and hedgerows similar to those of England, as well as a Quercus petraea woodland association floristically very similar to that in Great Britain. The change from the Atlantic conditions of Galicia to the relatively dry and continental climate of León and the still drier climate of north-western Castile was sudden and very striking, though it was interesting to note that familiar British plants such as Juncus spp. persisted in edaphically moist habitats.

From Madrid the Sierra de Guadarrama, with its interesting endemic montane flora, was visited, and then in the second part of the excursion the route turned south across the monotonous and intensively cultivated plains of La Mancha towards Andalusia. The gorge of Despeñaperros in the Sierra Morena which forms the frontier between Castile and Andalusia showed a striking change in the flora, and various southern species were seen for the first time. In the Guadalquivir valley near Córdoba the extensive fields of cotton were a remarkable sight for northern European botanists. The most memorable day on the second part of the excursion was the visit to the Sierra Nevada and the ascent of the Picacho de Veleta $(3,470 \mathrm{~m}$.), which is readily accessible by a road almost reaching the summit. The beautiful and varied alpine flora at altitudes above $2,500 \mathrm{~m}$., with its abundance of rosette plants and small spiny shrubs, seemed very strange to most members of the party, and very few of the species were familiar to those who had not visited the area before; one member of the party said that botanizing here was like "botanizing on the moon".

To an English botanist the foremost impression of this rapid survey of the flora and vegetation of Spain was of the immense wealth of species and the high degree of endemism. Travelling as we did, rapidly from place to place, the flora seemed to be inexhaustible and changed every day, even when the climatic and other conditions seemed to be similar. Everywhere endemic species, restricted to the Iberian Peninsula, or to some part of it, appeared to play a prominent part in nearly all the plant communities.

Another vivid impression was of the universal ecological importance of soil conditions. In all climatic regions of Spain, both dry and wet, and at all altitudes, there was a marked contrast between the flora of calcareous and non-calcareous soils, and no evidence was seen supporting the view that edaphic factors are less important in Continental countries than they are in the British Isles. Though the distinction of the calcicole and calcifuge floras was always apparent, the soil preferences of individual species were not always the same as in Britain. Thus 
Rhamnus catharticus, regarded in Britain as a typical calcicole, grows in the Sierra de Guadarrama on poor acid soils, and what a British botanist would regard as strange mixtures of calcifuge and calciole species were sometimes encountered.

It was of great interest to see the ecological range of some of our British plants in climates very different from our own. Some British species appeared to be extremely versatile, and one gained a new respect for the capabilities of such plants as Jasione montana when seeing them growing with Mediterramean xerophytes such as Dorycnium suffruticosum and Halimium umbellatum. In Soria province it was odd to see Arctostaphylos uva-ursi, regarded by British botanists as a typically northern plant, growing in pinewoods at no great altitude in company with typically Mediterranean shrubs such as Erica arborea and Lavandula stoechas.

It was not surprising to find that in the arid regions of Spain some plants which in Britain are confined to dry habitats require moist soil conditions ; thus Blackstonia perfoliata, which in Britain grows in relatively dry habitats, in the arid climato of los Monegros is restricted to damp places.

The excursion gave its members not only a unique opportunity of studying the natural and semi-natural plant communities of Spain, but also many fascinating glimpses of agricultural practices and the way in which these varied in the different regions. Many members were particularly interested in the peculiar system of shifting cultivation on the poor hill soils in Galicia where a long fallow stage of the tall leguminous shrub Sarothamnus welwitschii often intervenes between periods of cultivation of cereals and other crops. The Sarothamnus is cut for litter, and its seeds are sown with those of the cereal crop.

It is a pleasure to mention the generous hospitality which the members of the excursion everywhere received. Not only were the two leaders of the party, Profs. Rivas-Goday and Galiano, of the Faculty of Pharmacy, University of Madrid, unsparing in their efforts to help their foreign guests and answer their many questions, but also, in all the larger towns visited, hospitality was offered on a most generous scale. Since in Spain botany is generally linked with pharmacy, it was usually the local associations of pharmacists (Colegios de Farmacéuticos) to which the excursion was indebted for this hospitality, which not only included splendid banquets and official visits to places of scientific or artistic interest, but also such delightful features as displays of traditional dancing in Córdoba, Oviedo and Saragossa. The warmth of this welcome as well as the beauty and interest of the landscapes and the plants will make the Tenth International Phytogeographical Excursion live long in the memories of those who took part in it.

\section{NEWS and VIEWS}

Architectural Science at Sydney: Dr. H. J. Cowan

Dr. H. J. CowaN, lecturer in civil engineering in the University of Sheffield, is shortly to take up his appointment to the newly created chair of architectural science in the University of Sydney. Born in 1919, he graduated with first-class honours in the University of Manchester in 1939, obtaining his master's degree a year later. From 1940 Dr. Cowan served in the Royal Engineers until he was wounded in Holland in 1945. After gaining experience with firms of eivil engineering contractors and structural designers, he joined the teaching staff of University College, Cardiff, where he remained until he went to his present post in 1948. Since going to Sheffield, Dr. Cowan has carried out researches in reinforced and prestressed concrete and has published a number of papers and articles on these subjects in Britain and in the United States. His work on reinforced and prestressed concrete in combined kending and torsion is a noteworthy contribution in a new field of investigation, and for a thesis embodying some of this work he was awarded the Ph.D. degree. Dr. Cowan has taught structural engineering to students of architecture for the past five years, and he has delivered courses of public lectures on the theory of prestressed concrete design and on the design of concrete for ultimate strength.

\section{British Occupational Hygiene Society}

THE British Occupational Hygiene Society has recently been formed and will hold its first conference at the London School of Hygiene and Tropical Medicine on November 2. Proceedings will be opened by the Minister of Labour, Sir Walter Monckton, at 11 a.m.; Dr. T. Bedford will then deliver his presidential address. During the afternoon the following papers will be read and discussed:
"Measuring the Worker's Environment", by S. A. Roach, "The Problems of Chemical Toxicity", by D. G. Harvey, and "Occupational Hygiene and the Industrial Designer", by J. E. Braham. The Society hopes to promote knowledge of all matters which have a bearing on the health of men and women at their daily work. Regular conferences will be held at which both general problems and special technical aspects of occupational hygiene will be discussed. Particulars are available from the honorary secretary, Mr. P. C. G. Isaac, Public Health Engineering Laboratory, King's College, Newcastle upon Tyne, 1.

\section{National Smoke Abatement Society: Annual Conference in Glasgow}

THE twentieth annual conference of the National Smoke Abatement Society will be held in the Banqueting Hall, City Chambers, Glasgow, during September 30 -October 3 , and will be attended by some four hundred and fifty members and delegates, drawn mainly from local authorities, government departments and the fuel and power industries. On the first day the president of the conference, Prof. F. E. Tylecote, emeritus professor of medicine in the University of Manchester, will give his address, which will be on smoke and the local authority. This will be followed in the afternoon by the Des Voeux Memorial Lecture, which will be given by Sir John Charles, chief medical officer, Ministry of Health, who will speak on air pollution in relation to preventive medicine. The sessions for the remaining two days will deal with the following subjects (with the speakers shown in brackets): the London fog disaster of December 1952 (Dr. J. A. Scott, Dr. A. Parker and Arnold Marsh); report on smokeless zones (Dr. T. M. Clayton); production and use of solid smokeless fuels (Dr. F. J. Eaton, G. E. Hall 